\title{
On the Ideological and Political Education of College Students in the New Media Era
}

\author{
Chunfu Yang ${ }^{1, a}$, Dongliang Yang ${ }^{2, b}$, Weihong $\mathrm{Min}^{3, \mathrm{c}^{*}}$ and Yunping Zhang ${ }^{4, \mathrm{~d}}$ \\ ${ }^{1}$ College of Animal Science and Technology, Jilin Agricultural University, Changchun 130118, China \\ ${ }^{2}$ College of Information and Technology, Jilin Agricultural University, Changchun 130118,China \\ ${ }^{3}$ College of Food Science and Engineering, Jilin Agricultural University, Changchun 130118, China \\ ${ }^{4}$ Financial Department, Jilin Agricultural University, Changchun 130118, China \\ *The.corresponding author: Weihong Min, Professor, female, born in August, 1971, interested in \\ food science
}

àyangchunfu197242@163.com, b610557217@qq.com, '65817713@qq.com, d798301739@qq.com

Keywords: New media; College students; Influence; Opportunities and challenges; Countermeasures

\begin{abstract}
With the rapid development of modern information technology, new media provide a new carrier for the cultivation of talents. At the same time, it puts forward new challenges to the traditional educational model, and the university students are the main audience of new media development. New media gradually occupy the life of college students and have a profound impact on college students' ideology and behaviors. In order to better carry out the ideological and political education of college students in the new media era, this paper analyzes the influence of the new media age on the ideological and political education of college students, expounds the opportunities and challenges brought by the development of new media technology to the ideological and political education of college students, and proposes measures to carry out political and ideological education in the new media era.
\end{abstract}

\section{Introduction}

As a new way of communication and exchange between people, new media have been widely recognized by college students. The emergence and development of new media represented by the Internet has greatly changed the living environment and way of life of contemporary college students, thus making their values changed a lot. In this context, the ideological and political education of college students is mainly to help college students to improve the ideological and political quality, to train them into the successor of China's socialist modernization. Therefore, in the process of ideological and political education, it is of great significance to make full use of new media to improve the level of teaching.

\section{Influence of New Media on Ideological and Political Education of College Students}

The Way Students Get information has Changed. With the universal use of the Internet, college students have access to information from a single way to complex and multiple changes. This means that while obtaining information through the Internet, it will bring some detrimental problems to the physical and mental development of college students. In terms of a variety of means 
of communication, compared with writing and other traditional ways of communication, college students prefer microblogging, WeChat moment to express their emotions, which makes college students get great satisfaction, and become more inclined to this way of communication between man and machine.[1]

The Way of Learning and Thinking of College Students has Changed. The emergence of new media is quietly changing the traditional classroom teaching and learning. In fact, this is a double-edged sword. On one hand, college students can use multimedia through the network to obtain more rich learning materials and share resources; the other hand, we must also recognize the role of teachers in the traditional classroom, the teacher can filtering the knowledge and information for students so as to guide positive guidance to students,. Among the massive new media information, there are some negative and distorted value and vulgar information, which may have adverse effects on students.[2] The emergence of new media technology has greatly changed the way of learning. Previously, students learn knowledge mainly through the classroom and textbooks, and now they prefer independent learning relying on online resources.

The Interpersonal Relationship of College Students has Changed. New media technology has the equality and interactivity, and can effectively expand students' interpersonal space. The emergence of new media provides a good platform for the interaction between the people and breaks the traditional way of communication. Friends and family can use SMS, WeChat, QQ and other real-time chat software, which makes college students break through the time and space constraints. At the same time, anonymous communication provides a platform to express their views and expand the interpersonal space. However, as students are exposed to a virtual network world for a long time, they reduce or even ignore the real-life exchanges, affecting the normal exchange in reality.

\section{Opportunities and Challenges for the Development of New Media Technology to College Students' Ideological and Political Education}

Development Opportunities. First, ideological and political education contains rich and colorful contents. The infinite resources presented by new media form the world's largest "library", which greatly enriched the ideological and political education connotation as well as the new educational content. It also makes the practice of socialist core values to achieve the Chinese dream, carry forward the traditional culture and other "high" ideological and political education theme vivid and easy to be understood. [3]Through the new media, students can choose their own messages and carry out "self-cultivation" education and achieve "individualized" according to their own needs and interest on the Internet Second, ideological and political education platforms are diversified.[4] Under the influence of the development of new media technology, ideological and political education in colleges and universities gradually bid farewell to the traditional educational model, information can be fully shared and spread. In the virtual network space, college students can not only take the initiative to absorb learning resources to obtain educational information, but also are subtly influenced by the various educational topics on the Internet. On the other hand, the huge amount of information, the rapid spread of college students has also been favored, which greatly enriches the ideological and political education means of college students, and it is very important to enhance the effectiveness of ideological and political education work. Third, trust between the subject and object of the ideological and political education has enhanced. New media have fundamentally changed the way people communicate relying on information technology based on the equality of interaction. The social characteristics of the people is completely concealed in the 
communication, the two sides of education can use WeChat, microblogging, forums and other online chat platforms for "no scruples" communication to understand the most authentic ideas of educators, which not only shortens the interpersonal psychologic distance, reduces the awareness of psychological prevention, but also greatly reduces the gap between teachers and students to enhance mutual trust between each other, thus reversing the traditional ideological and political education face to face, point-to-point embarrassment and inadequacy to achieve good educational results. [5]

Face the Challenge. First, the mainstream values are subject to multiple shocks. The purpose of ideological and political education of college students is to use the socialist core values to lead the students to develop a good attitude towards life and become qualified successors of the cause of socialism. However, the beliefs and thoughts of college students in the new media era are influenced by multiple values and ideology, which blurs and even destroys their ideals and beliefs for college students who lack social experience and identification ability to certain degree. [6]If not properly guided, it can easily lead to the deviation of college students and cognitive distortions, resulting in political desalination and the emergence of ideological crisis. Second, the authority of ideological and political education workers face challenges. The universal use of microblogging and WeChat makes a lot of college students become mobile phone addicts and also gradually changes or even shocks the ideological and political education workers in the main position. The traditional teaching methods are increasingly neglected by students, but college students are more inclined to obtain their own ability to identify new knowledge, leading to the teachers' teaching advantage no longer prominent. And it is more passive for workers lack of media literacy at work. Third, the traditional model of ideological and political education is facing a great threat. In the new media era, most students will choose to communicate through WeChat, microblogging, network forums and other virtual space in an anonymous way.[7] On the surface, there are more and more choices of communication channels for college students, and they are more and more simple and convenient, but the absence of excessive freedom in the virtual world makes words and deeds cannot be standardized, and it is difficult to protect the authenticity. Because long-term indulgence in virtual space leads to eccentricity, isolation from the reality, loss of self and other psychological problems are commonplace. Against the new media background, the ideological and political education model reform rate is far behind the pace of development of new media technology.

\section{Countermeasures of College Students' Ideological and Political Education in the New Media Era}

Change the Concept of Education. First of all, change the traditional educational philosophy and strive to keep pace with the times, educators need to establish a modern information concepts and advanced consciousness, so that the traditional indoctrination teaching can be changed to the two-way interactive mode. Secondly, adhere to the main theme in the process of ideological and political education, give full play to the role of new media, to be good at using the new media communication platform, publicize the correct public opinion, expand the content and scope of ideological and political education, and actively use healthy thinking to guide contemporary college students.[8]

Integrate the Ideological and Political Education into the New Media. First of all, correctly guide the schools to further improve the facilities, build a website and establish an ideological and political education system on the website, carry out campus cultural activities and social practice activities, and correctly guide the ideological direction of college students; second, enrich the ideological and political education platforms, and make full use of QQ, MSN and other network 
tools to narrow the distance between the two sides of education, achieve one-to-many communication, accurately grasp the ideological movement of students to solve the problems of weak teaching staffs;[9] finally, carry out a variety of theme activities to make college students gain a more in-depth understanding of and can correctly use the new media, creating a positive cultural atmosphere so as to stimulate students' innovative consciousness and innovative spirit and improve students' innovative ability.

Establish a Team of Ideological and Political Education with New Media Literacy. In the new media era, the ideological and political education workers of college students should have the following basic qualities: First, we must have firm ideals and beliefs, unswervingly follow the socialist road with Chinese characteristics, and play a correct guiding role in cultivating the correct ideological and political view of college students. Second, we must have solid professional theoretical quality and have the ability to use basic Marxist principles to solve practical problems in the complex environment with diversified ideologies.[10] Third, we must have strong new media technology quality, take the initiative to learn new media knowledge and skillfully use new media carrier, so that individuals can not only become "tangible" guide of positive ideological and political education, but also "intangible" publishers and managers of useful information in the new media background.

Comprehensively Enhance the Overall Quality of College Students. Constantly strengthen the political ideals and beliefs of college students, establish the correct realm of socialist ideals, regularly carry out ideological and political education and training work to promote the enthusiasm of college students and make them take the initiative into the ideological and political education, break the traditional education model for in-depth innovation. To enhance the quality of ideological and political education work, new media technology should be combined so that students can pay more attention to details and effectively change the mode of thinking in the learning process.

\section{Summary}

After all, it takes ten years to grow tree, but a hundred years to rear people. Ideological and political education is related to the healthy and comprehensive development of college students, so its importance is undeniable. For ideological and political education in the new media era, it is both opportunity and challenge. Only by grasping the opportunity and paying attention to challenges while making full use of the advantages of new media, timely adjusting work thoughts and methods and taking the initiative to innovate ideological and political work mechanism can we more effectively carry out ideological and political work and improve efficiency.

\section{References}

[1] J.L.Wang: Some Thoughts on Strengthening the Cultivation of College Students' Socialist Core Values by Using New Media [J], Journal of Ideological \& Political Education, 2014(11).(in Chinese)

[2] L.J.Lei, J.Zh.Xiao: A Study on the Strategy of Improving the Discourse Right of Moral Education in Colleges and Universities from the Perspective of New Media[J],China Electric Power Education, 2013( 13),(in Chinese)

[3] Chinese Academy of Social Sciences. Social Psychology Blue Book: China 's Social Mentality Research Report ( 2015) [M].2015.(in Chinese) 
[4] Ch.Zhou: On the Innovative Dimension of Moral Education in Colleges and Universities in the New Media[J].School party building and ideological education, 2014( 11).(in Chinese)

[5] H.Huang:Microblogging and Teenagers Moral Education: Dilemma and Outlet - Based on the Theory of Narrative[J].Educational Science Research,2015(8) .(in Chinese)

[6] Y.J.Zheng: An Analysis of the Actual Effect of Ideological and Political Education in Colleges and Universities under the New Media Environment[J].Journal of Ideological \& Theoretical Education, 2011( 11).(in Chinese)

[7] H.X.Xu:A Study on the Dilemma of Graduate Moral Education in the Media[D]. Huazhong Normal University Doctoral Dissertation, 2014.(in Chinese)

[8] Y.J.Zheng: On the Actual Effect of Ideological and Political Education in Colleges and Universities under the New Media Environment[J].Journal of Ideological \& Theoretical Education, 2011( 11).(in Chinese)

[9] Ch.Zhou: On the Innovative Dimension of Moral Education in Colleges and Universities in the New Media[J].School party building and ideological education, 2014(11).

[10] Q.W.Deng: The Influence of New Media on College Students' Ideology and Morality and the Countermeasures [D]. Guilin: Guangxi Normal University,2011.3. (in Chinese) 